\title{
UŽITNÉ VZORY JAKO INSPIRACE PRO BYZNYS
}

\section{UTILITY MODELS AS A BUSINESS INSPIRATION}

\author{
Petr Dlask*1, Jaroslava Tománková \\ ${ }^{1}$ CTU in Prague, Thakurova 7, Prague, 166 29, Czech Republic, dlask@fsv.cvut.cz, +420224353729 \\ ${ }^{2}$ VSEM, Narozni 2600/9A, 15800 Prague, Czech Republic
}

\begin{abstract}
Abstrakt - CZ
Současná doba nabízí velmi široké možnosti a podmínky pro individuální podnikatelské nápady. $\mathrm{Na}$ první pohled by se mohlo zdát, že omezení bude plynout ze získání potřebných finančních prostředků. Skutečnost je taková, že finanční prostředky jsou problémem až ve druhé řadě. Na prvním místě je kvalita podnikatelského nápadu. Pokud bude záměr dostatečně kvalitní a invenční, není problém získat potřebné investiční prostředky. Široký potenciál invence v sobě skrývají užitné vzory registrované prostřednictvím Úřadu průmyslového vlastnictví. Autoři v článku uvádějí pohled na podané inovační postupy spojené s tradičním stavebním materiálem, kterým je kámen. Jeho používání ve stavebnictví má dlouhodobou tradici a nové výrobní a zpracovatelské postupy nabízejí nové možnosti pro netradiční byznys.
\end{abstract}

\section{Klíčová slova - CZ}

užitný vzor, topná kamenná deska; průsvitný kámen; impregnovaný kámen

\section{Abstract - EN}

Nowadays, there are many possibilities and conditions for individual business ideas. At first glance, it may seem that restrictions come from not getting the necessary funds. The fact is that funds are only a secondary issue. The primary one is the quality of the business idea. If the idea is good and sufficiently inventive, raising the necessary investment resources is not a problem. Utility models registered through the Industrial Property Office present a broad potential for invention. The authors offer an insight into the submitted innovative practices associated with traditional building materials, such as stone. Its use in construction has a long-standing tradition, and new manufacturing and processing methods offer new opportunities for unconventional business.

\section{Keywords - EN}

Utility model, heating stone; translucent stone; impregnated stone

\section{JEL Classification}

O33 - Technological Change: Choices and Consequences, Diffusion Processes

L74 - Construction

DOI: https://doi.org/10.14311/bit.2016.01.03

Editorial information: journal Business \& IT, ISSN 2570-7434, CreativeCommons license (c) (i) published by CTU in Prague, 2016, http://bit.fsv.cvut.cz/ 


\section{Úvod}

Všechny podnikatelské aktivity jsou iniciovány snahou pokrýt volné místo na trhu nebo uspokojit poptávky zákazníků po novém zboží nebo po nových službách. $V$ těchto aktivitách jsou bohužel zahrnuty i neúspěšné pokusy, které se nesetkaly s předpokládanou odezvou na trhu. Problémy neúspěchu mohou být velmi rozmanité. Často se lze setkat s nízkou mírou invence a racionální odvahy, která by odlišila počínající podnikatelský záměr od ostatních. Technologické inovační aktivity mohou podnítit nové přiležitosti pro rychlejší rozvoj průmyslu i ekonomiky. Podle analýzy provedené v rozvíjejících se ekonomikách zemí EU nepatří Česká republika mezi nejúspěšnější státy z hlediska rozvoje technologie měřeného podle získaných grantů, technologických patentů, užitných vzorů a dalších parametrů, jako jsou průmyslové vzory a ochranné známky [1].

Navýšení potenciálu invence je možné docílit aplikací myšlenek obsažených $v$ registrovaných užitných vzorech nebo patentech. Jejich obsah bývá z hlediska podnikání často nedoceněn. Autoři si chrání svoje nová řešení, ale následně už nemají potenciál na jejich využití v praxi [2]. Hlavním cílem tohoto textu je upozornit na inovační potenciál registrovaných patentů, užitných vzorů apod. na príkladu dosažení netradičních vlastností tradičního materiálu při využití nových technologických postupů při jeho zpracování, které byly ve spolupráci ČVUT v Praze a specializovaného výrobce Granit Holec registrovány na ÚPV jako užitné vzory.

\section{Užitné vzory a jejich vědecké pozadí}

Pátráním po nových zkušenostech a řešením nových problémů se posouvají možnosti využívání materiálů. Pokud se budeme pohybovat v oblasti stavebnictví, velmi často se zde ubíráme standardními cestami. Vyšší cenu a potenciál dalšího rozvoje však přinese využívání tradičních surovin netradičním způsobem. Standardními vědeckými postupy $v$ této souvislosti jsou empirické metody, kterými se zjištují unikátní vlastnosti hmotné substance. $V$ našem prípadě jsme se zaměřili na kamenný materiál v jeho prrírodní podobě. Pro zjištóvání jeho netradičních vlastností je třeba používat další metody z oblasti empiriky, jako jsou tvrdé

- metriky měřitelných parametrů,

- pozorování jevů

- experimenty.

Experimenty jsou v oblasti tohoto materiálu velmi důležitým článkem na cestě od vědeckého zkoumání po praktické využití zjištěných skutečností. Aplikace pro využití informací, které jsou obsaženy $v$ užitných vzorech, využívají postupy vyhledávacího výzkumu v databázích národních a mezinárodních organizací, jako např. WIPO (World Intellectual Property Organization [3]) nebo DPMA (Deutsches Patent- und Markenamt [4]).

\section{Rešerše zpracovaných užitných vzorů}

Klasické stavební materiály (jako je beton, keramika, kámen) se v praxi používají ve většině případů standardním způsobem. Nejčastěji je to limitováno cenovými možnostmi investora. Takové chování však nepřinese žádný technologický ani technický posun kupředu. Užitné vzory, které budeme dále komentovat, jsou výsledkem poptávky trhu po vlastnostech, kterými kamenný materiál běžně nedisponuje. Jedná se např́klad o

- nenasákavost (hloubkové uzavření pórů v materiálu),

- průsvitnost (při zachování konstrukční a transportní pevnosti),

- kombinace s materiály s dlouhou (neomezenou) životností (s nízkou uhlíkovou stopu), 
- vysokou odolnost povětrnostním vlivům při nízkých tloušt́kách (např. při ochraně pevných i pohyblivých součástí výplní stavebních otvorů).

Některé vlastnosti se zdají na první pohled jako běžné. Například odolnost proti povětrnostním vlivům je bazální charakteristika kamenného materiálu. Její využití pro obklad pohyblivých částí výplní stavebních otvorů však vyžaduje další netradiční technické postupy a úpravy. Za běžných podmínek by taková kombinace tradičního materiálu a požadavků na netradiční vlastnosti nebyla možná. Nemožnost by se nedala odbourat ani investováním většího množství finančních prostředků. $V$ takovém př́padě přichází na řadu vývoj speciálních výrobních a technologických postupů, které prolomí bariéru možného řešení na základě vědeckých a praktických postupů uvedených výše. Demonstrace těchto přístupů bude uvedena na následujících užitných vzorech:

- Tenkostěnný topný panel s nízkou uhlíkovou stopou

- Soustava pro impregnaci kamenných prvků

- Průsvitný kamenný prvek

- Exteriérový obklad okenního rámu a okenního křídla

Uvedené užitné vzory byly zpracovány ve spolupráci mateřské organizace autorů (ČVUT v Praze) a specializovaným výrobním podnikem (GRANIT HOLEC).

\section{Tenkostěnný topný panel s nízkou uhlíkovou stopou}

Motivace: použití prrírodního materiálu pro zařízení sálavého tepla. Řešení v sobě kombinuje materiály s dlouhým cyklem životnosti. Cílem bylo zrychlit náběh sálavé teploty při použití karbonového drátu.

Popis: Podle užitného vzoru číslo 23379 existuje technické řešení, které se týká zařízení určeného $\mathrm{k}$ vytápění zejména obytných místností a užitných prostor. Topný prvek tvoří spirála karbonového drátu (volně upraveno podle [5]). Zařízení je vhodné instalovat do místností, kde je vyžadováno rychlé dosažení tepelně vnímané pohody. Odporový drát, který je standardně používán, je nahrazen matriálem s dlouhou (neomezenou) životností.

V současnosti se tepelné pohody interiérového prostředí dosahuje:

- instalací přímotopných elektrických panelů,

- klasických teplovodních radiátorů,

- instalací podlahového vytápění.

Mezi nevýhody uvedených řešení patří jejich pevné spojení s nosnou konstrukcí stavby, případně jejich značné nároky na spotřebu elektrické energie. Při poruše odporového kabelu je nutný zásah do konstrukce při demontáži. Navržená materiálová kombinace se snaží tuto skutečnost výrazně minimalizovat.

Provozů a místností, kde je možné navrhované řešení použít, může být více. Tenkostěnný topný panel podle uvedeného návrhu Ize využít zejména k:

- vytápění obytných místností,

- vytápění užitných prostor,

- vytápění koupelen a šaten,

- vytápění další provozů, kde je vyžadováno rychlé dosažení tepelně vnímané pohody.

Kromě těchto standardních aplikací můžeme hledat další nestandardní aplikační situace. Použití Ize navrhnout do provozů vyžadujících vyšší nároky na hygienické předpisy společně s požadavkem na 
udržování požadované teploty povrchu. Takové místo mohou být například tepelně vyhřívané pulty v hromadných výdejnách jídel, menzách apod.

Na obrázku 1 je uveden pohled na tenkostěnný topný panel z mramorové desky. Testovací elektronika ovládání pro nastavení a dosažení rychlého náběhu teploty je osazena pro testování po pravé straně. Panel má tloušt'ku $20 \mathrm{~mm}$ po okrajích a vnitřní část je frézována na tloušt́ku 8 až $9 \mathrm{~mm}$. Tento malý rozměr umožňuje rychlý náběh povrchové teploty a rovnoměrné šíření tepla po celé desce topného panelu. Detail na obrázku 2 zobrazuje zadní plochu tenkostěnné desky, kde je uložen karbonový kabel do silikonového lože. Spirála je rovnoměrně roztažena po zadní ploše a do okrajů frézovaného materiálu.
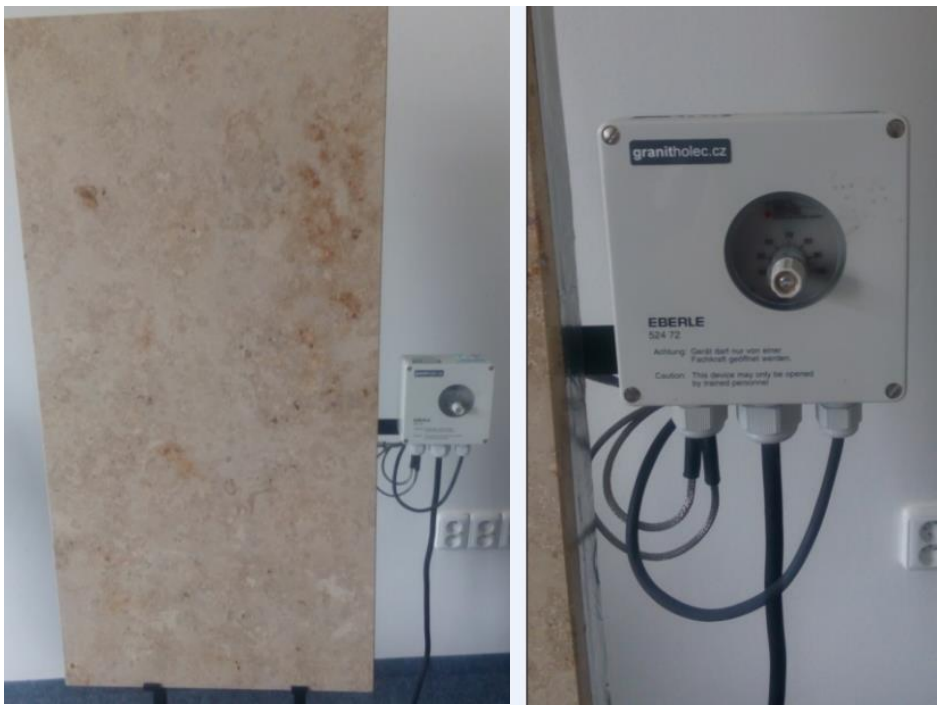

Obrázek 1: Pohled na tenkostěnný topný panel a testovací elektroniku ovládání pro nastavení a dosažení rychlého náběhu teploty (zdroj: autoři)

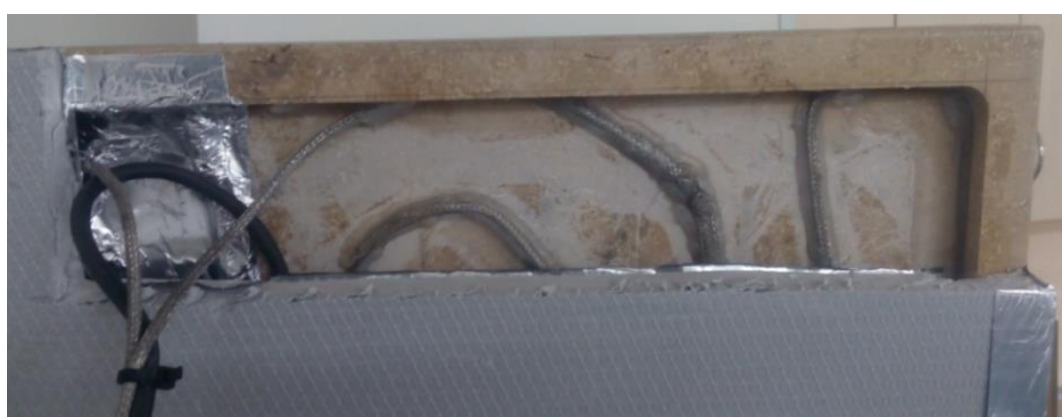

Obrázek 2: Pohled na zadní odkrytou tenkou kamennou desku frézovanou do požadované tloušt'ky s instalovaným karbonovým drátem (zdroj: autoři)

Pro minimalizování úniků tepla do zadní části panelu je možné nalepit na celou plochu kamenné desky hliníkovou folii, která odráží generované teplo zpět. Uvedené technické řešení má následující prínosy:

- použití materiálů s dlouhým (neomezeným) životním cyklem,

- rychlý náběh sálavé teploty při použití karbonového kabelu,

- tradiční materiál navozující príijemné prostředí interiéru,

- rozmanité možnosti aplikačních provozů a situací. 


\section{Soustava pro impregnaci kamenných prvků}

Motivace: prodloužení trvanlivosti a vylepšení vlastností kamenných výrobkủ. Řešení si kladlo za cíl vylepšit a zvládnout dosavadní běžné impregnační postupy.

Popis: Podle užitného vzoru číslo 24102 existuje technické řešení, které se týká zařízení určeného $k$ podtlakové impregnaci výrobků z kamene (volně upraveno podle [6]). Aktuální praxe volí pro impregnaci klasické nátěrové postupy. Mezi nevýhody takového řešení patři omezená hloubka napuštění impregnačního roztoku do kamenné desky.

Tyto nedostatky odstraňuje impregnační vak pro kamenné výrobky (viz obrázek 3). Jeho podstatou je, že je tvořen neprodyšným materiálem (například neopren, pogumovaná látka, měkčené PVC). Impregnovaný materiál je umístěn ve vzduchotěsném, zavíracím vaku. Vak je napojen vyztuženou podtlakovou hadicí pomocí rychlospojky na jednotku pro vytvoření podtlaku (vakuová pumpa). Po obvodu je vak opatřen neprodyšným uzávěrem (zipem). Rozměry vaku je možné individuálně upravit podle rozměrů ošetřovaného výrobku.
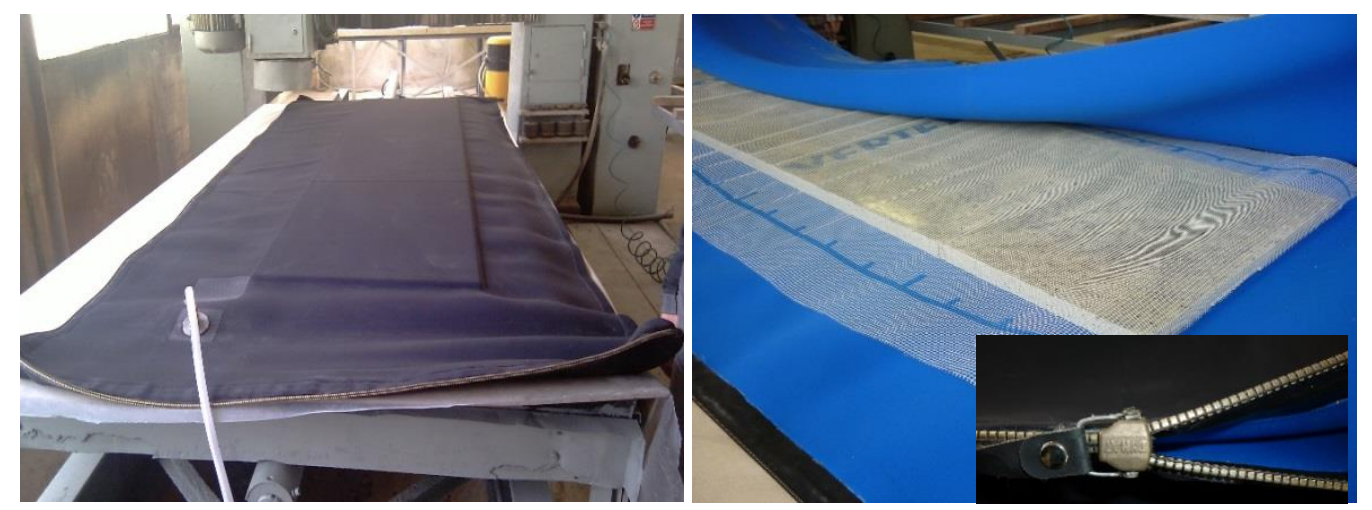

Obrázek 3: Impregnační vaky s ošetřovaným kamenným prvkem. Vlevo probíhající proces impregnace s připojenou vývěvou. Vpravo ukládání kamenného prvku a detail vzduchotěsného uzávěru impregnačního vaku (zdroj: autoři)

Impregnační vak Ize vytvořit ve dvou variantách.

1. impregnovaný prvek je uložen v podtlakovém vaku, který je tvořen neprodyšným neoprenovým materiálem. Vnitřní prostor je uzavřen neprodyšným uzávěrem. Povrch kamenného prvku je před odsáváním vzduchu pomocí vyztužené podtlakové hadice napuštěn penetračním nátěrem s uloženou perlinkovou tkaninou, která zajištuje rovnoměrné odcházení vzduchu při realizaci podtlaku. Roztok je zároveň udržován rovnoměrně na povrchu kamenného prvku.

2. kamenný prvek je uložen na topném panelu (infrazářiči), který zvyšuje účinnost proniknutí penetračního roztoku do prvku. Ostatní podmínky jsou stejné jako u varianty 1.

Vytvořeným podtlakem pomocí vývěvy se uvolní vzduch, který je obsažen v otevřených pórech kamenné desky. Vzduch, který je obsažen v pórech kamenné desky, expanduje z kamenných pórů ven, při opětovném snižení podtlaku, až na atmosférický tlak (vypuštění vaku). Atmosférický přetlak okolního vzduchu natlačí impregnační roztok do pórů kamene (do větší hloubky) tento cyklus Ize i několikrát opakovat).

Uvedené technické řešení má následující přínosy:

- možnost transportu zařízení za kamenným výrobkem,

- možnost impregnace kamenného výrobku v jakékoliv poloze,

- rychlé dosažení hydrofobizačního efektu,

- finanční dostupnost zařízení, nevyžadujícího složitá technická řešení,

- snadnou výrobu vaku z neprodyšného materiálu pro různé rozměry impregnovaných prvků. 


\section{Průsvitný kamenný prvek}

Motivace: kamenný materiál je často používán k obkladům interiérů i exteriérů. Pro získání přístupu přirozeného osvětlení je nutné zajistit narušení obkladové stěny osvětlovacím otvorem. Eliminaci tohoto rušivého faktu nabízí nové řešení, které se snaží využívat průsvitnosti tenké kamenné desky.

Popis: Podle užitného vzoru číslo 24994 existuje možnost výroby průsvitného kamenného prvku (volně upraveno podle [7]). Podstatou řešení je sendvičové spojení navzájem zapečených vrstev. Sendvič je tvořen tenkou kamennou deskou typu kamenný plech o tloušt́ce $2 \mathrm{~mm}$ až $3 \mathrm{~mm}$ ze světlopropustného materiálu. Pohledová plocha desky je vyleštěná. $V$ sendviči je dále umístěna zapékací fólie, která je umístěná na druhé, rovněž vyleštěné ploše kamenné desky a kalené sklo o tloušt'ce $v$ rozmezí $8 \mathrm{~mm}$ až $12 \mathrm{~mm}$ umístěné na této zapékací fólii.

Tenká kamenná deska je z kamene, který umožňuje broušení na tloušt́ku kamenného plechu. Lze použít napríklad mramor, světlou žulu nebo onyxy.

Boční strany sendvičového spojení jsou opatřeny rámem pro izolování zapékací fólie od okolních vlivů, např́klad plastovým rámem. $V$ jiných provedeních je možné boční stranu ochránit vrstvou pryskyřice či neutrálním silikonem nebo PVB fólií.

Výhodou takto vytvořeného sendviče z kamenného materiálu je, že je možné brousit ho až na tloušt́ku kamenného plechu. Kalené sklo pak tvoří nosnou vrstvu (alternativa voštiny) a je možné dosáhnout prvku o rozměru až $300 \times 170 \mathrm{~cm}$.

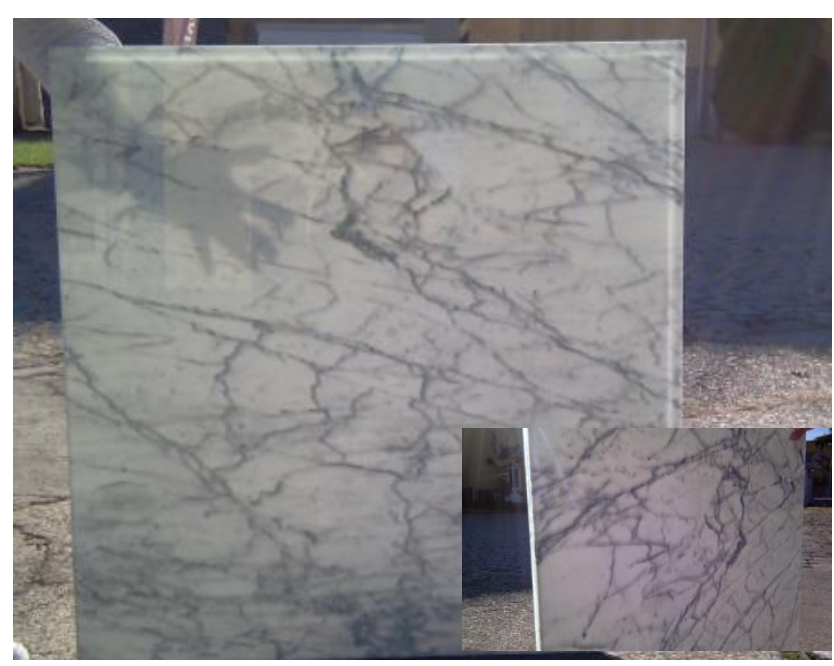

Obrázek 4: Pohled na tenkou kamennou desku s průsvitnými vlastnostmi. V detailu kresba mramorové desky (zdroj: autoři)

Na obrázku 4 je představen vzorek průsvitného kamenného obkladu z mramorové desky. Dále se předpokládá použití světlé žuly. Vhodné jsou také onyxy, které jsou již samy o sobě částečně světlopropustné. Samozřejmě, že Ize použít pro kamennou desku i jiný druh kamene za podmínky, že se jedná o materiál, který propouští světlo a zároveň umožní broušení až na tloušt́ku kamenného plechu, jak je uvedeno výše.

Uvedené technické řešení má následující přínosy:

- využití netradiční vlastnosti tradičního stavebního materiálu - průsvitnosti kamene,

- možnost přisvětlení obložených prostor, které jinak nemají přístup k přirozenému světlu,

- odlehčení konstrukce aplikací tenké kamenné desky,

- možnost provádět velkoplošné konstrukce,

- aplikace pro designové návrhy interiérů,

- možnost používání efektů umělého podsvícení. 


\section{Exteriérový obklad okenního rámu a okenního křídla}

Motivace: výplně otvorů se $v$ dnešní době provádějí z tradičních materiálů, jako je dřevo, plast, kov. Navrhované řešení s použitím kamenného materiálu se $v$ dosavadním stavu techniky prozatím nevyskytuje. Motivačním prvkem bylo přinést netradiční vzhled oken společně se zajištěním dlouhodobé životnosti. Současným efektem je také využití vlastností užitného vzoru, týkajícího se velmi tenké kamenné desky, kterou je možné použít jako exteriérový obkladový materiál [8].

Popis: Podle užitného vzoru číslo 25258 je možno navrhovat kamenný obklad rámů oken a okenních křídel (volně upraveno podle [9]). Tradiční typy okenních výplní vykazují relativně obdobné doby životnosti. Různí se ale $v$ nákladech na provozní výdaje, které mohou být významně odlišné. Materiálové varianty se volí rovněž v závislosti na architektonických požadavcích. Některé kombinace materiálů, zejména plast-kov, se vyskytují častěji, jiné kombinace, kov-dřevo, se používají méně často. Limitující pro tato stávající řešení jsou nároky na kvalitní provedení, šetrnou dopravu a zabudování výrobku. Pro tradiční řešení můžeme konstatovat, že

- stávající výrobky vyžadují pravidelnou údržbu,

- stávající výrobky mají relativně krátkou dobu životnosti,

- některé provozní opravy jsou obtížně realizovatelné,

- některé provozní opravy vyžadují obnovu funkčních prvků oken.

Uvedené nedostatky odstraňuje exteriérový obklad okenního rámu a okenního křídla podle technického řešení užitného vzoru [9]. Vnější viditelná plocha okenního rámu a okenního kř́́dla je opatřena na přední ploše obkladem tvořeným tenkou kamennou deskou připevněnou $k$ okennímu rámu nebo kř́́dlu přes lepící lože. Tento obklad je po celém obvodu na hraně dosedající na ostění nebo zasklení opatřen silikonovým těsněním.

Prostor mezi spodní částí vnější plochy křídlového obkladu a k ní přivrácenou vnitřní hranou rámového obkladu je po celé styčné délce opatřen pryžovým těsněním. Tenké kamenné desky tvořící rámový a kř́ídlový obklad mají tloušt́ku v rozmezí 2 až $6 \mathrm{~mm}$.
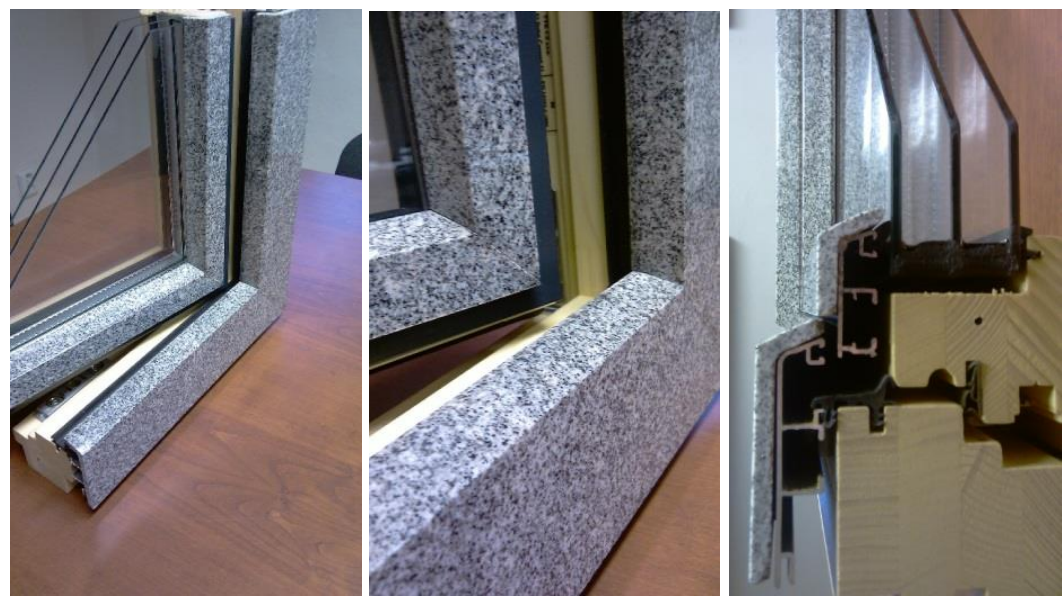

Obrázek 5: Obklad pevných a pohyblivých součástí dřevěného okna kamennými deskami frézovanými do minimálních tlouštěk (zdroj: autoři)

Na obrázku 5 jsou uvedeny detaily obkladu rohového detailu otevíravého okna. Nosným prvkem pro kamenné desky jsou hliníkové lamely přichycené do dřevěné konstrukce okna. $V$ pravé části obrázku je vidět, že řešení je možné aplikovat také pro trojnásobné izolační zasklení.

Vzhledem k tomu, že šíře materiálu pro exteriérové krytí rámu oken, nebo křídel oken nepřesahuje běžně 200 mm, Ize kotoučovou pilou tento řez provádět v délkách 2000 mm a více. Získá se tak kamenný (páskový) prvek pro exteriérovou část konstrukce oken, která je bezúdržbová a vykazuje mimořádně dlouhou životnost. 
Uvedené technické řešení má následující přínosy:

- kamenný obklad esteticky posouvá vzhled okenní výplně pro použití v netradičních architektonických aplikacích,

- použitím tenké kamenné desky se získá krátkodobá výhoda pro manipulaci a montáž,

- použitím tenké kamenné desky se získá dlouhodobá výhoda v průběhu životního cyklu okna,

- Ize předpokládat velmi nízké nároky na údržbu vzhledem k vlastnostem kamenného povrchu,

\section{Výsledky}

Vzhledem k uvedeným př́kladům možného aplikačního použití kamenného materiálu podle dohledaných registrovaných užitných vzorů je možné konstatovat, že při zvládnutí nových výrobních postupů dosáhneme i u tradičních materiálů netradičních vlastností.

Nové výrobní postupy vyžadují vybavení, kterým běžně disponují výrobní podniky zabývající se aplikací kamenného materiálu pro různé použití, lze je tedy využívat v praxi bez vysokých pořizovacích nákladů na vybavení. Podstatný pro inovativní postup je nápad na nové možnosti využití kamenných prvků a poté použití metod z oblasti empiriky a experimentální řešení.

V tomto ohledu je velmi výhodná spolupráce výrobních podniků a výzkumných pracovišt, která umožňuje dovést původní myšlenku či nápad až do úspěšné realizace a poté i registrace formou patentu nebo užitného vzoru. Taková spolupráce mezi mateřskou organizací autorů (ČVUT v Praze) a specializovaným výrobním podnikem (GRANIT HOLEC) vedla ke zpracování výše uvedených užitných vzorů a jejich úspěšnému ověření v praxi výrobního podniku.

\section{Závěr}

Primárním cílem článku bylo upozornit na možnosti využití inovativních přístupů obsažených v registrovaných užitných vzorech v podnikatelské praxi pro získání nových podnikatelských príležitostí. Tyto možnosti byly prezentovány na př́kladech vyhledání netradičního použití tradičního stavebního materiálu. Databáze citovaných užitných vzorů skrývá realizační (podnikatelské) možnosti, které nejsou doposud využívány v širším měřítku. Pro materiálovou kombinaci s kamennými prvky lze definovat prínosy jako:

- dlouhá (neomezená) životnost,

- vysoká odolnost vůči povětrnostním vlivům při nízkých tloušt́kách kamenných prvků,

- netradiční architektonická a estetická použití,

- snižování provozních nákladů,

- aplikace pro designové návrhy interiérů i exteriérů

V článku se jedná o inspiraci byznysu na základě registrovaných užitných vzorů, které se mohou využít ve specifických prípadech, ne běžně realizovaných (kamenné okno, průsvitný kámen, impregnovaný kámen). Při využití těchto vzorů už není třeba přijít s novou myšlenkou, protože ta je $\mathrm{k}$ dispozici, ale pouze s ověřením poptávky po nabízených řešeních. 


\section{References}

[1] JEMALA, M. New research study on technology patents progress in developing EU countries. International Journal of Agile Systems and Management, pp. 116-136. ISSN:1741-9174

[2] BERAN, V., SEDLÁČEK, M., and MARŠíK, F. A new bladeless hydraulic turbine. Applied Energy. 2013, 104pp. 978-983. ISSN 0306-2619. Available online at: http://www.elsevier.com/locate/apenergy

[3] WIPO. WIPO Search. World Intellectual Property Organization. Available online at: http://www.wipo.int/tools/en/

[4] DPMA. DEPATISnet. Deutsches Patent- und Markenamt. Available online at: https://depatisnet.dpma.de/DepatisNet/depatisnet?window=1\&space=menu\&content=index\&action= einsteiger

[5] ÚPV. Zápis č.: 23379 Tenkostěnný topný panel s nízkou uhlíkovou stopou. Úřad průmyslového vlastnictví. Available online at:

https://isdv.upv.cz/webapp/webapp.pts.det?xprim=1752943\&lan=cs\&s majs=\&s puvo=Dlask\%20Petr \&s naze $=\& s$ anot $=$

[6] ÚPV. Zápis č.: 24102 Soustava pro impregnaci kamenných prvků. Úřad průmyslového vlastnictví. Available online at:

https://isdv.upv.cz/webapp/webapp.pts.det?xprim=1805905\&lan=cs\&s majs=\&s puvo=Dlask\%20Petr \&s naze $=\& s$ anot $=$

[7] ÚPV. Zápis č.: 24994 Průsvitný kamenný prvek. Úřad průmyslového vlastnictví. Available online at: https://isdv.upv.cz/webapp/webapp.pts.det?xprim=1885523\&lan=cs\&s majs=\&s puvo=Dlask\%20Petr \&s naze $=\&$ s anot $=$

[8] ÚPV. Zápis č.: 24993 Velmi tenká kamenná deska. Úřad průmyslového vlastnictví. Available online at: https://isdv.upv.cz/webapp/webapp.pts.det?xprim=1882658\&lan=cs\&s majs=\&s puvo=Dlask\%20Petr \&s naze $=\& s$ anot $=$

[9] ÚPV. Zápis č.: 25258 Exteriérový obklad okenního rámu a okenního křídla. Úřad průmyslového vlastnictví. Available online at: https://isdv.upv.cz/webapp/webapp.pts.det?xprim=1914797\&lan=cs\&s majs=\&s puvo=Dlask\%20Petr \&s naze $=\& s$ anot $=$

\section{Acknowledgement}

Zpracování uvedených funkčních vzorků bylo podporováno rozvojovým projektem C49 s názvem Laboratoř technicko-ekonomického rozhodování (Decision Laboratory) na Fakultě stavební ČVUT v Praze. Projekt byl realizován za podpory a financován z prostředků Ministerstva školství, mládeže a tělovýchovy. 